\title{
HOW DO AGRICULTURAL BIOGAS INVESTMENTS AFFECT CZECH FARMS?
}

\section{Špička, J.}

The article aims to evaluate the impacts of strategic investments in biogas plants on the economic sustainability and vulnerability of farms with a special focus on investment subsidies. Data spanning 148 farms from the Czech Republic over a thirteen-year period (2004-2016) are used to estimate random effects panel regression models to quantify the short-term and long-term economic sustainability and vulnerability of integrated energy production in the context of mixed type farming. Investments in biogas plants can negatively affect the viability of agricultural companies in the short term because farms which invest in biogas suffer from debt pressures due to inadequate revenues in the construction phase. However, in the long term, the effects of biogas plant operations are positive: economic sustainability is enhanced and vulnerability is reduced mainly due to public support for renewable energy production in the form of feed-in tariffs and green bonuses. Comparing farms that received investment subsidies with nonparticipating farms indicates a high deadweight loss effect which means that programme participants would undertake a similar investment without programme support. However, the investment subsidies improve recipients' cash flows.

Keywords: agriculture, biogas, Czech Republic, subsidies, sustainability, vulnerability JEL Classification: M21

\section{Introduction}

Agricultural biogas plants contribute to sustainable energy production and consumption. Moreover, they can diversify farms' cash flows and render them more stable (Sgroi et al., 2018). "Agro-energy" covers a broad political, economic and social context. It is a crucial element of the Europe 2020 Strategy (Bartolini et al., 2017) and biogas plants have been subsidised by indiviudal EU member states, as well as through the central EU budget, for a long time (Eder \& Mahlberg, 2018). However, the integration of biogas plants into agricultural enterprises has stirred up discussions about land use changes (Börjesson \& Tufvesson, 2011) and the ability to influence agri-food markets and security (Britz \& Delzeit, 2013). 
Much research in recent years has focused on the multidimensional impacts of agricultural biogas plants. Overall, the evidence suggests that biogas adoption is economically, socially and environmentally feasible in rural areas (Abbas et al., 2017). Nevertheless, building or upgrading agricultural biogas plants is a major strategic issue for farmers because, even with subsidies, these represent high investment expenditures.

Barring technical parameters, a farmer should consider not only economic profit but also changes in capital and production structures which alter the risk of corporate failure (Brealey et al., 2008). Financial aspects dominate over technological and environmental issues (Brudermann et al., 2015) for profit maximising agents operating within the neoclassical economics framework. However, the extent to which these agents and that framework can reasonably and robustly be transferred to empirical contexts has been the subject of long standing debate and disagreement (Anderson \& Ross, 2005). Academics working in this domain and other salient stakeholders have determined that the additional source of income provided by biogas as well as the advantages it offers through reduced energy costs associated with self-provision represent the two critical economic strengths of having these plants on agricultural lands (Brudermann et al., 2015). Agricultural biogas plants have a positive effect on profit (earnings before interest and tax), cash flow and value added of agricultural enterprises (Guenther-Lübbers et al., 2016; Iotti \& Bonazzi, 2016; Špička \& Krause, 2013). However, the extant literature has not considered the effects of these plants on economic sustainability more broadly, nor decomposed financial performance indicators into revenues and costs.

Results from a partial equilibrium model analysis by Britz and Delzeit (2013) revealed that "while profits in the agricultural sector increase, food consumer[s] face higher prices, and subsidies for biogas production are passed on to electricity consumers". The profitability of biogas production changes with location, size and processing technique: specifically, profits are higher in regions with a small amount of agricultural land, large heterogeneity in agricultural area and high livestock density with comparatively large areas needed for disposal (Delzeit \& Kellner, 2013).

Biogas plants can also affect operating costs. Production of electricity and heat has an impact on energy savings (Yasar et al., 2017). Manure management and the size of the agricultural biogas plant affect cost efficiency (Delzeit \& Kellner, 2013). It is cost-efficient to use manure first in biogas plants in regions with high livestock density; farmers use the surplus in those areas with lower nutrient levels. The maximum profitable manure transport distance is $800 \mathrm{~km}$, depending on the state of manure (Garbs \& Geldermann, 2018). Regarding the size of biogas plants, the least-cost plant capacity depends on the share of available land used for silage maize production and ranges in model calculations from $575 \mathrm{kWel}(5 \%$ share) to $1150 \mathrm{kWel}$ (20\% share) (Walla \& Schneeberger, 2008).

The financial strength of potential and existing plant operators is perceived as being the main weakness associated with extending the use of agricultural biogas plants. Low financial 
strength relates to liquidity shortages of farms. The financial leeway of operators is more constrained when plant capacities are underutilised (Brudermann et al., 2015) which increases the average fixed cost per unit of output. Technical efficiency also impacts on the economics of biogas plants. A recent study of 86 Austrian biogas plants revealed that only $7 \%$ of small biogas plants $\left(\leq 100 \mathrm{~kW}_{\mathrm{el}}\right)$ are technically efficient exhibiting increasing returns to scale while $40 \%$ of medium-sized (101 to $500 \mathrm{kWel}$ ) and $89 \%$ of large-sized plants (above $500 \mathrm{kWel}$ ) are technically efficient (Eder \& Mahlberg, 2018). Investment expenditures required to build or upgrade biogas plants are often high relative to the equity, profit and financial reserves of agricultural enterprises. Agricultural enterprises mostly use bank loans to co-finance these expenditures and thus have to draw up a business plan to acquire these loans (Bonazzi \& Iotti, 2015). As such, in the short term, debt ratios tend to increase significantly (Špička \& Krause, 2013) as do the credit risks borne by investors.

Despite it is difficult to predict variations in farm incomes due to adverse weather conditions and price volatility (Krause \& Machek, 2018), agricultural enterprises in Central Europe have a low propensity for insolvency mainly by virtue of prevailing subsidies (Špička, 2015). The currently available agricultural subsidies generally consist of income support (direct payments, subsidies to less-favoured areas) and environmental payments for externalities and public goods. Moreover, there is direct operational support for producing energy from biogas plants including feed-in tariffs and green bonuses (Slaboch \& Hálova, 2016). Current subsidies for renewable energy production, available from the Rural Development Programme, are a non-trivial component of the total subsidies mix, accounting for an average of $17 \%$ of current subsidies in mixed type farming in 2016 (Hanibal, 2017). However, investments in the construction or upgrading of biogas plants are often an encumbrance for agricultural enterprises, notwithstanding the availability of these subsidies and low-interest loans.

This article focuses on the economic pillar of sustainable development. Unlike previous studies in this domain, the impacts of biogas plants on the economic sustainability and vulnerability of farms are evaluated using long-term farm-level data. Supported and unsupported farms are also compared and contrasted in terms of their differential economic sustainability and vulnerability. To this end, indicators of economic sustainability and business failure prediction models (vulnerability models) decomposed into separate variables are employed. This work offers a novel contribution to the literature in the form of a long-term economic assessment of a controversial means of renewable energy production. Agricultural biogas plants are often criticised in terms of their suboptimal use of public funds and their adverse environmental impacts on soil quality. By evaluating the effects of biogas investments on the economic sustainability of farms, including the probability that farms will go bankrupt, this article fills a gap in the economics literature, which has hitherto concentrated on the partial economic effects of agricultural biogas plants based on case studies which do not yield generalisable results (Ginting et al., 2018; Sgroi et al., 2018; Vochozka et al., 2018). By contrast, this article utilises data from a representative sample of biogas plants in the Czech Republic. This country has experienced a boom in the 
construction of such plants since it acceded to the EU in 2004. The results are relevant and important for farmers who decide to build or upgrade biogas plants, financiers such as bank managers and policymakers who decide about investment and subsidies.

The sustainability, or lack thereof, of farm operations is a function of economic as well as environmental, social and innovation dimensions. In operational terms, "economic sustainability is generally viewed as economic viability, namely whether a farming system can survive in the long term in a changing economic context" (Latruffe et al., 2016). European definitions of economic viability follow the concept of opportunity cost while definitions emanating from the USA and Canada approach economic viability in terms of meeting the income needs of the farm family (O'Donoghue et al., 2016). Measurement of economic sustainability necessitates indicators of economic viability (profitability liquidity, stability and profitability) and some studies also refer to 'autonomy' as an indicator of freedom (Bossel, 1999). There are financial aspects to autonomy (Latruffe et al., 2016) including debt pressures, farm or household diversification. non-agricultural activities, offfarm income and subsidy dependence (any policy reform that reduces subsidies could put farm sustainability at risk). All of these aspects are relevant in the context of agricultural biogas plants because these plants are co-financed by bank loans, they represent an important non-agricultural activity and they can increase farms' dependence on subsidies when government entities institute feed-in tariffs and green bonuses.

Farms that are neither economically viable nor sustainable are classified as economically vulnerable (O'Donoghue et al., 2016). Economically vulnerable farms have a high risk of business failure. Financial distress costs result from companies' financial difficulties. The emergence and accentuation of financial problems is directly proportional to debt growth. However, it is important to also consider the profitability of the company because the market value of a firm is determined by its earning power as well as by the risks to which its underlying assets are exposed (Modigliani \& Miller, 1958, 1963). Thus, it is not reasonable to make partial evaluations as per what has been published so far on this topic. Hence, the approach adopted in this paper draws on capital structure theory because this follows a multivariate approach considering more financial aspects of the investor.

Business failure has been defined and measured in different ways in the literature. In definitional terms, herein, business failure is conceived as a sequence of several financial situations that lead to the closure of the firm (Morris, 1997). Thus we follow Megginson's trade-off model (Megginson, 1997) which is based on Modigliani and Miller's capital structure theory (Modigliani \& Miller, 1958, 1963). The essence here is the identification of an optimal capital structure by seeking a compromise between the advantages and disadvantages of debt used in relation to the company's value. The trade-off model expresses the value of a levered firm in terms of an unlevered firm, adjusted for the present value of tax shield, financial distress costs and the agency costs of debt and equity (Megginson, 1997). 
In terms of measuring business failure, the most common methods for estimating the probability that a firm will go bankrupt are credit scoring models which are based on multiple discriminant analysis (Agarwal \& Taffler, 2008; Altman \& Hotchkiss, 2005), probability theory (Wilcox, 1973), logistic regression (Ohlson, 1980; Zmijewski, 1984), artificial neural networks (Boritz et al., 1995; Wilson \& Sharda, 1994), support vector machines (Huang et al., 2004; Chen, 2011), rough sets (Mckee, 2000; Yeh et al., 2014), casebased reasoning (Kolodner, 1993; Watson, 1997), decision trees (Cho et al., 2010; Klepac \& Hampel, 2017) and genetic algorithms (Min et al., 2006; Shin \& Lee, 2002). No singular tool is universally better than all other tools (Alaka et al., 2018). This article applies three widely used scoring models based on multiple discriminant analysis. Although arguably less accurate than neural networks and support vector machines (Alaka et al., 2018), these models are more tractable from the perspective of empirical application and can be adjusted for specific sectors and countries.

\section{Data and Methods}

\subsection{Data and sampling procedure}

The dataset consists of 148 Czech agricultural enterprises which reported financial data and acreage in 2004-2016 when the boom in agricultural biogas plants was supported by the Rural Development Programme (RDP). In the Czech Republic, the construction and upgrading of agricultural biogas plants was subsidised mainly through measures 311 Diversification into non-agricultural activities and 312 Support for the creation and development of enterprises. Eligible expenditures for 311 and 312 included construction of decentralised facilities for the use of renewable sources of fuel and energy (biomass or biogas) - for heating or production of electric energy; heating stations, heating or energy networks, biogas stations (homogenising tanks, reactors, biogas containers, storage tanks, cogeneration units, heat exchangers, etc.). Measure 312 focused specifically on microenterprises (Ministry of Agriculture, 2008).

The sample of biogas plants was randomly selected from the population of on-farm (i.e. integrated) agricultural biogas plants. Biogas plants which work as individual companies were not included in the sample because such plants do not enable the evaluation of wholefarm effects. Moreover, there are no agricultural biogas plants set up as subsidiary companies of farms, often because of hidden ownership interests. There are 80 supported biogas plants from the RDP (participants) and 68 biogas plant that did not receive investment support in the sample (nonparticipants). The nonparticipants either did not apply at all or their applications were rejected due to formal or factual errors. The Czech Biogas Association provided data on licenced agricultural biogas plants (Czech Biogas Association, personal communication, January 5, 2018) whilst the Ministry of Agriculture shared data about investment subsidies of biogas plants (Ministry of Agriculture, personal communication, January 12, 2018). 


\subsection{Economic sustainability}

Economic sustainability is related to the concepts of cash flow and liquidity and is calculated as per Equation 1.

Economic sustainability $=$ net cash income $-[$ change in assets used between years + change in debt use between years]

where net cash income is net income plus non-cash costs (European Commission Directorate-General for Agriculture and Rural Development, 2016). The higher the value of this indicator, the greater the economic sustainability of the farm, and thus in operational terms the lower the longer-term risk for financial loan providers. This indicator does not accommodate off-farm employment or opportunity costs. However, because the sample of farms used herein is constituted mainly by medium and large mixed type farms, off-farm employment and opportunity costs are of low relevance. Companies running such farms in the Czech Republic employ professional management personnel and do not tend to rely on family labour (Forti, 2017).

\subsection{Economic vulnerability}

The risk of corporate failure is measured by credit scoring models based on multiple discriminant analysis. Three different vulnerability models are considered: i) Altman's Z' score model for private firms; ii) model IN05 for Czech companies which puts more emphasis on debt and solvency rate; and iii) G-index developed for agricultural companies. Altman's Z' score and IN05 model exhibit high reliability for predicting financial distress in the Czech Republic (Camska, 2016; Manasova, 2008) whereas the G-index has been shown to be reliable for agricultural companies (Kopta, 2009).

Altman's Z' score model for private firms (Altman \& Hotchkiss, 2005) can be expressed as per Equation 2.

$$
\mathrm{Z}^{\prime}=0.717 \mathrm{X}_{1}+0.847 \mathrm{X}_{2}+3.107 \mathrm{X}_{3}+0.420 \mathrm{X}_{4}+0.998 \mathrm{X}_{5}
$$

where

- $\mathrm{X} 1=($ current assets - current liabilities $) /$ total assets

- $\mathrm{X} 2$ = retained earnings $/$ total assets

- $\mathrm{X} 3$ = earnings before interest and taxes / total assets

- $\mathrm{X} 4=$ book value of equity / total liabilities

- $\quad \mathrm{X} 5=$ revenues $/$ total assets

Zones of discrimination:

- $\quad Z^{\prime} \geq 2.9$ - "Safe" Zone 
- $1.23<\mathrm{Z}^{\prime}<2.9$ - “Grey” Zone

- $\quad Z^{\prime} \leq 1.23$ - "Distress" Zone (vulnerable companies)

Next, the IN05 model for Czech companies (Neumaierova \& Neumaier, 2005) is delineated in Equation 3.

IN05 $=0.13 \mathrm{X}_{1}+0.04 \mathrm{X}_{2}+3.97 \mathrm{X}_{3}+0.21 \mathrm{X}_{4}+0.09 \mathrm{X}_{5}$

where

- $\mathrm{X} 1=$ total assets $/$ total liabilities

- $\quad \mathrm{X} 2$ = earnings before interest and taxes / interest payable $(\max$. limit $=9)$

- $\quad \mathrm{X} 3$ = earnings before interest and taxes / total assets

- $\mathrm{X} 4=$ total revenues $/$ total assets

- $\quad \mathrm{X} 5$ = current assets $/$ short-term liabilities

Zones of discrimination:

- $\quad$ IN05 $\geq 1.6$ - "Safe" Zone

- $\quad 0.9<$ IN05 < 1.6 - “Grey” Zone

- $\quad$ IN05 $\leq 0.9$ - "Distress" Zone (vulnerable companies)

Finally, Equation 4 specifies the G-index for agricultural enterprises (Gurcik, 2002).

$$
\mathrm{G}=3.412 \mathrm{X}_{1}+2.226 \mathrm{X}_{2}+3.277 \mathrm{X}_{3}+3.149 \mathrm{X}_{4}-2.063 \mathrm{X}_{5}
$$

where

- $\mathrm{X} 1$ = retained earnings $/$ total assets

- $\mathrm{X} 2$ = earnings before interest and taxes / total assets

- $\quad \mathrm{X} 3$ = earnings before interest and taxes / total revenues

- $\mathrm{X} 4$ = cash flow $/$ total assets (where cash flow = net profit + non-cash costs)

- $\mathrm{X} 5=$ stock $/$ total revenues

Zones of discrimination:

- $\mathrm{G} \geq 1.8$ - "Safe" Zone

- $\quad-0.6<\mathrm{G}<1.8$ - "Grey” Zone 
- $\mathrm{G} \leq-0.6$ - "Distress" Zone (vulnerable companies)

These three credit scoring models are not strongly correlated (maximum bivariate Pearson's correlation coefficient is 0.421 ( $p<0.001$ ) between Altman and G-index).

\subsection{Panel regression models}

Parameters were estimated from a strongly balanced panel (with 148 cross-sectional units observed over 12 periods) using the following procedures. Separate regressions were estimated for different response variables, namely, vulnerability scores (Z', IN05 and G) and an indicator of economic sustainability. First, a Durbin-Wu-Hausman test (DWH) is employed to test whether a fixed or random effects model is optimal for our data based on consistency and efficiency criteria. Random effects are preferred under the null, thus with $p$ $=0.04<0.05$, there is some evidence in favour of the fixed effects model variant. However because we are close to the null here and because fixed effects models cannot estimate parameters on time invariant regressors (Allison, 2009; Greene, 2012) there are arguments in favour of opting for random effects estimation in this case.

If the DWH test does not indicate significant differences in the coefficients, then the Breusch-Pagan Lagrange multiplier (BPLM) test shows whether to use a random effect or pooled OLS model. The BPLM test works under the null hypothesis of no random effects (Dougherty, 2011). In case of the random effects model, an approach following Swamy and Arora (1972) estimates the variance components ("within" and "between" variances) in panel data. Since panel data have both a time-series and a cross-sectional dimension, one might expect that, in general, Arellano's robust estimation (Arellano, 2003) of the covariance matrix would require handling both heteroscedasticity and autocorrelation (the HAC approach). This approach has already been utilised in the applied literature (Špička et al., 2017).

The default robust estimator is that suggested by Arellano (2003), which is HAC provided the panel is of the "large n, small T" variety (that is, many units are observed in relatively few periods). The Arellano estimator is as per Equation 5.

$$
\hat{\sum}_{A}=\left(X^{\prime} X\right)^{-1}\left(\sum_{i=1}^{n} X_{t}^{\prime} \hat{u}_{i} \hat{u}_{i}^{\prime} X_{i}\right)\left(X^{\prime} X\right)^{-1}
$$

where $\mathrm{X}$ is the matrix of regressors (with the group means subtracted, in the case of fixed effects) $\hat{u}_{i}$ denotes the vector of residuals for unit $\mathrm{i}$, and $\mathrm{n}$ is the number of cross-sectional units. To deal with autocorrelation and heteroskedasticity, the robust estimator of the covariance matrix was selected in all cases.

Let's assume the general model as per Equation 6.

$$
y_{i t}=\beta_{0}+\sum_{j=1}^{k} \beta_{j} X_{j i t}+\mu_{i}+v_{i t}
$$


where $y_{i t}$ is the response variable (credit scores, financial indicators), $X_{j}$ are observed explanatory variables, $\mu_{i}$ is an unobservable and time-independent individual specific effect, $v_{i t}$ is a disturbance term with mean zero and variance $\sigma$. The subscripted index i refers to the unit of observation $(i=1, \ldots, N)$ and $t$ refers to the time period $(t=1, \ldots, \mathrm{T})$. To evaluate temporal effects, dummy variables $d t_{-} 1-d t_{-} 13$ are included which measure the effect of each year of 2004-2016.

A Wald test for joint significance of the time dummies was used to confirm whether or not they should be included in the model (Greene, 2012). Based on this, the model with binary regressors was selected to evaluate the average ceteris paribus effect of operating biogas plants on changes in the economic indicators. The specific vulnerability models are delineated as per Equation 7.

$y_{i t}=\beta_{0}+\beta_{1} x_{1 i t}+\beta_{2} x_{2 i j}+\beta_{3} x_{3 i}+\sum_{j=2}^{13} \gamma_{j} d_{j}+\mu_{i}+v_{i t}$

where

$y_{i t}=$ one of the response variables - vulnerability scores $\left(Z^{\prime}\right.$, IN05, G).

$x_{1 i t}=$ OPER, operation of the biogas plants $(0=$ no biogas plant in operation, $1=$ one biogas plant in operation, 2 = two biogas plants in operation or increased power of biogas plant etc.).

- $x_{2 i j}=$ PAYMENT, payment of investment subsidy from the RDP received $(0=$ farm has not received investment support for biogas plant so far, $1=$ farm has received investment support for biogas plant from the RDP for the first time, $2=$ farm received investment support for biogas plant from the RDP for the second time etc.). Farms which repeatedly received investment support usually built a second biogas plant or upgraded an existing plant.

- $x_{3 i}=$ PARTICIP, time-invariant regressors distinguish participants and nonparticipants $(0=$ farm has never received investment support from the RDP for a biogas plant in the period $2004-2016,1=$ farm has received investment support from the RDP for a biogas plant in the period 2004 - 2016 at least once).

- $d_{j}=$ year-specific time dummies. Variable $\mathrm{d} 2$ takes one for the year 2005 and zero otherwise, variable $\mathrm{d} 3$ takes one for the 2006 and zero otherwise etc.

Then, the vulnerability scoring models significantly influenced by the biogas plant and/or the investment subsidy are decomposed to reveal the partial effects. The same model was used for analysis of partial effects where $y_{i t}$ is a partial financial ratio indicator of the vulnerability model. 
The specific model for economic sustainability is delineated as per Equation 8 .

$y_{i t}=\beta_{0}+\beta_{1} x_{1 i t}+\beta_{2} x_{2 i j}+\beta_{3} x_{3 i j}+\beta_{4} x_{4 i}+\sum_{j=2}^{12} \gamma_{j} d_{j}+\mu_{i}+v_{i t}$

where

- $\quad y_{i t}=$ economic sustainability indicator.

- $x_{1 i t}=$ LIC, start of operation of the biogas plant $(0=$ no biogas launched, $1=$ biogas plant launched). This indicates short-term economic sustainability, or lack thereof, because it reflects just the starting point of a biogas plant.

- $x_{2 i j}=$ BGP, operation of at least one biogas plant $(0=$ no biogas plant in operation, $1=$ at least one biogas plant in operation). This indicates the long-term economic sustainability, or lack thereof, under the operation of the biogas plant.

- $\quad x_{3 i j}=$ PAYMENT, payment of investment subsidy from the RDP received $(0=$ farm has not received investment support for biogas plant so far, $1=$ farm has received investment support for biogas plant from the RDP for the first time, $2=$ farm received investment support for biogas plant from the RDP for the second time etc.).

- $x_{4 i}=$ PARTICIP, time-invariant regressors distinguishes participants and nonparticipants $(0=$ farm has never received investment support from the RDP for a biogas plant, 1 = farm has received investment support from the RDP for biogas plant at least once).

- $d_{j}=$ year-specific time dummies. Variable $\mathrm{d} 2$ takes one for the year 2006 and zero otherwise, variable d 3 takes one for the 2007 and zero otherwise etc.

\section{Results and Discussion}

Table 1 summarises the basic structural and economic features of the farms with biogas plants in the sample. Inferential tests of difference (dependent sample t-tests) are used to compare between the initial year 2004 and the end of the period 2016 when all farms in the sample operate at least one biogas plant. The average utilised agricultural area is more than 2,000 hectares which reflects the tendency towards large agricultural enterprises in the Czech Republic. The sample represents medium-sized companies $(\min =218.74$ ha in 2016$)$ to extremely large agricultural enterprises $(\max =9614.44 \mathrm{ha})$. The mixed type of farming is optimal for biogas plant operations because it provides on-farm crop and livestock inputs. The share of permanent grassland in the total utilised agricultural area ranged between 0 and $100 \%$ in 2016, with an average of $18.18 \%$. This is typical for intermediate less-favoured areas. The grassland surplus has the potential for biogas production. A recent study declared that the use of grassland biomass for biogas production is consistent with supporting 
ecosystem services provision (Kizeková et al., 2018). The area of the sampled farms did not significantly change in the period $2004-2016(p=0.2803>0.05)$, thus the biogas plants have not significantly impacted on land area.

Table 1 | Descriptive statistics and t-tests $(n=148)$

\begin{tabular}{|c|c|c|c|c|c|c|c|c|c|}
\hline Agricultural land & Mean & SD & Min & Max & diff & -44.84 & & t statistic & -1.08 \\
\hline 2004 & 2453.50 & 1470.44 & 452.87 & 9699.35 & $95 \% \mathrm{Cl}$ & -126.61 & 36.93 & DF & 147 \\
\hline 2016 & 2408.65 & 1493.81 & 218.74 & 9614.44 & SE & 41.38 & & $p$-value & 0.2803 \\
\hline Permanent grassland & Mean & SD & Min & Max & diff & -4.54 & & t statistic & -0.44 \\
\hline 2004 & 406.99 & 382.65 & 0.00 & 2082.55 & $95 \% \mathrm{Cl}$ & -24.83 & 15.74 & DF & 147 \\
\hline 2016 & 402.45 & 370.00 & 0.00 & 1815.38 & SE & 10.26 & & $p$-value & 0.6588 \\
\hline Tangible assets & Mean & SD & Min & $\operatorname{Max}$ & diff & 4488.28 & & t statistic & 14.06 \\
\hline 2004 & 3455.06 & 2573.03 & 261.77 & 15721.42 & $95 \% \mathrm{Cl}$ & 3857.47 & 5119.09 & DF & 147 \\
\hline 2016 & 7943.34 & 5813.06 & 1380.50 & 41149.50 & SE & 319.20 & & $\mathrm{p}$-value & 0.0000 \\
\hline Livestock & Mean & SD & Min & Max & diff & -60.55 & & t statistic & -2.78 \\
\hline 2004 & 766.43 & 522.52 & 0.00 & 3709.62 & $95 \% \mathrm{Cl}$ & -103.53 & -17.57 & $\mathrm{DF}$ & 147 \\
\hline 2016 & 705.88 & 553.53 & 0.00 & 4314.15 & SE & 21.75 & & $\mathrm{p}$-value & 0.0061 \\
\hline Current assets & Mean & SD & Min & Max & diff & 1308.89 & & t statistic & 9.45 \\
\hline 2004 & 2499.03 & 1748.81 & 334.19 & 10601.62 & $95 \% \mathrm{Cl}$ & 1035.18 & 1582.59 & DF & 147 \\
\hline 2016 & 3807.92 & 3052.25 & 412.23 & 23661.96 & SE & 138.50 & & $p$-value & 0.0000 \\
\hline Total liabilities & Mean & SD & Min & Max & diff & 2095.38 & & t statistic & 8.93 \\
\hline 2004 & 2608.87 & 2570.97 & 207.85 & 23788.65 & $95 \% \mathrm{Cl}$ & 1631.66 & 2559.09 & DF & 147 \\
\hline 2016 & 4704.24 & 3138.92 & 267.38 & 24246.54 & SE & 234.65 & & $p$-value & 0.0000 \\
\hline Bank loans & Mean & SD & Min & Max & diff & 2057.35 & & t statistic & 12.23 \\
\hline 2004 & 804.93 & 821.57 & 0.00 & 5905.88 & $95 \% \mathrm{Cl}$ & 1724.87 & 2389.83 & $\mathrm{DF}$ & 147 \\
\hline 2016 & 2862.28 & 2166.19 & 0.00 & 18044.62 & SE & 168.24 & & $p$-value & 0.0000 \\
\hline Sales & Mean & SD & Min & Max & diff & 556.81 & & t statistic & 4.19 \\
\hline 2004 & 3497.86 & 3002.96 & 532.58 & 23621.92 & $95 \% \mathrm{Cl}$ & 294.41 & 819.21 & DF & 147 \\
\hline 2016 & 4054.67 & 3270.87 & 336.23 & 22744.77 & SE & 132.78 & & $p$-value & 0.0000 \\
\hline EBIT & Mean & SD & Min & Max & diff & 4224.34 & & t statistic & 13.16 \\
\hline 2004 & 317.26 & 350.87 & -1048.73 & 2555.15 & $95 \% \mathrm{Cl}$ & 3589.82 & 4858.87 & DF & 147 \\
\hline 2016 & 4541.61 & 4 101.17 & -116.75 & 25094.81 & SE & 321.08 & & $p$-value & 0.0000 \\
\hline
\end{tabular}

Notes: Agricultural land and permanent grassland are measured in hectares, all other variables are in thousand $€$; EBIT = earnings before interest and taxation.

The value of tangible assets defines the size of farms from a different perspective. Here, the t-test shows a significant increase in these assets between 2004 and 2016 due to investments in buildings and equipment for energy production $(p<0.05)$. By contrast, there was a substantial decrease in the average value of animals (livestock) from 766.43 to 705.88 thousand $€(p<0.05)$. This can be explained in terms of farm-specific structural changes and the general trend of decreasing livestock production in the Czech Republic. Farms decide whether to use maize to feed animals or as an input to biogas plants. In fact, biogas plants are operational in highly-productive agricultural areas with direct competition between food, feed and energy crops in limited areas of land (Demartini et al., 2016). Farmers often increase production of maize for renewable energy production which indirectly increases its profitability. This empirical finding accords with simulation-based results from Germany where biogas production has led to an intensification of land use, especially to increases in cultivation of grass and maize silage instead of meadows and other crops (Ostermeyer \& Schonau, 2012). This may have deleterious environmental 
consequences, however, novel pre-treatment technology that allows substitution of purposegrown crops by farming residues (such as husk or straw) is available. This innovation improves economic, environmental and social acceptance of renewable energy production in agricultural biogas plants (Vochozka et al., 2018). Another recent study has suggested that "sustainable alternatives to the use of maize (animal manure, straw and grass) are present in all the member states of the EU28 to an extent that is sufficient to ensure a continuous progressive development of the European biogas sector" (Meyer et al, 2018).

Further, farms operating biogas plants increased their liabilities, especially bank loans. Biogas plants represent non-trivial investments and farms often co-finance these investment expenditures by the combination of own equity, public investment support and bank loans. Total investment expenditures tended to range between $20 \%$ and $80 \%$ of total assets before investment (in 2004). Sometimes investment expenditures exceeded $100 \%$ of total assets (18.6\% of the sample). The average amount of bank loans increased from 804.93 thousand $€$ in 2004 to 2862.28 thousand $€$ in 2016 ( $p<0.05)$.

Next, Table 2 compares electrical and thermal outputs between subsidised farms and nonparticipants. There is some variability in terms of electrical and thermal power across biogas plants in the Czech Republic. The Czech Biogas Association (Czech Biogas Association, personal communication, January 5, 2018) reports 394 agricultural biogas plants in the Czech Republic with an average electrical power $796 \mathrm{~kW}$ and thermic power $772 \mathrm{~kW}$ which does not differ significantly from the reported power in Table 2 ( $p=0.2783$ $>0.05$ ). In Table 2, installed electricity and thermal power do not differ significantly between supported and unsupported farms. Thus, public investment support does not lead to building biogas plants with higher energy output.

Table 2 | Installed electrical and thermic output per farm in 2016

\begin{tabular}{|c|c|c|c|c|c|c|c|c|c|}
\hline Electrical output & Mean & SD & Minimum & Maximum & difference & 67.40 & & t statistic & 1.03 \\
\hline 0 & 800.47 & 348.91 & 320 & 1953 & $95 \% \mathrm{Cl}$ & -61.68 & 196.49 & DF & 146 \\
\hline 1 & 867.88 & 431.91 & 250 & 2863 & SE & 65.31 & & $p$-value & 0.3038 \\
\hline Thermal output & Mean & SD & Minimum & Maximum & difference & 48.54 & & t statistic & 0.79 \\
\hline 0 & 800.90 & 340.02 & 354 & 1806 & $95 \% \mathrm{Cl}$ & -73.64 & 170.72 & DF & 146 \\
\hline 1 & 849.44 & 401.96 & 232 & 3127 & SE & 61.82 & & $\mathrm{p}$-value & 0.4337 \\
\hline
\end{tabular}

Notes: Output measured in $\mathrm{kW} ; 0=$ nonparticipants, $1=$ participants.

The following results were derived from application of DWH and BPLM tests.

A) Economic vulnerability:

- Altman's score: DWH statistic $\mathrm{H}=7.562$, p-value 0.9109. This indicates no significant differences in the coefficients and suggests some evidence against the fixed effect model. Thus, the random effects model variant was applied. The BPLM test $\mathrm{LM}=3979.41(p<0.0001)$ also provides support for using a random effects model. 
○ IN05: DWH statistic $\mathrm{H}=0.896$, $\mathrm{p}$-value $=1$. This indicates no significant differences in the coefficients and suggests some evidence against the fixed effect model. The BPLM test LM = $144.979(p<0.0001)$ also provides support for using a random effects model.

○ G-index: DWH statistic H = 3.20609, p-value 0.999. This indicates no significant differences in the coefficients and suggests some evidence against the fixed effect model. The BPLM test LM = 2402.26 ( $p<0.0001)$ also provides support for using a random effects model.

B) Economic sustainability: DWH statistic $H=7.25872$, p-value 0.9243 . This indicates no significant differences in the coefficients and suggests some evidence against the fixed effects model. The BPLM test LM = 48.9953 ( $p<0.0001)$ also provides support for using a random effects model.

Table 3 | Comparison of three vulnerability models $(n=1924)$

\begin{tabular}{|c|c|c|c|c|c|c|c|c|c|c|c|c|}
\hline \multirow[b]{2}{*}{ Variables } & \multicolumn{4}{|c|}{ Dependent variable: Altman } & \multicolumn{4}{|c|}{ Dependent variable: IN05 } & \multicolumn{4}{|c|}{ Dependent variable: Gindex } \\
\hline & coeff. & & SE & $z$ & coeff. & & SE & $\mathrm{t}$ & coeff. & & SE & $z$ \\
\hline const & 2.016 & $* * *$ & 0.089 & 22.575 & 1.536 & $* * *$ & 0.309 & 4.966 & 0.553 & $* * *$ & 0.100 & 5.528 \\
\hline OPER & -0.636 & $* * *$ & 0.092 & -6.921 & -0.108 & & 0.068 & -1.589 & -0.146 & $*$ & 0.077 & -1.886 \\
\hline PAYMENT & 0.502 & $* * *$ & 0.078 & 6.434 & -0.010 & & 0.128 & -0.078 & 0.169 & $*$ & 0.087 & 1.953 \\
\hline PARTICIP & -0.186 & & 0.128 & -1.455 & 0.133 & & 0.194 & 0.688 & -0.091 & & 0.143 & -0.637 \\
\hline$d t \_2$ & 0.013 & & 0.030 & 0.434 & -0.693 & & 0.472 & -1.469 & 0.010 & & 0.058 & 0.177 \\
\hline dt_3 & 0.076 & $* *$ & 0.037 & 2.082 & -0.343 & & 0.326 & -1.052 & 0.129 & $* *$ & 0.059 & 2.174 \\
\hline dt_4 & 0.343 & $* * *$ & 0.060 & 5.731 & -0.320 & & 0.425 & -0.753 & 0.516 & $* * *$ & 0.068 & 7.595 \\
\hline dt_5 & 0.166 & $* *$ & 0.070 & 2.362 & -0.325 & & 0.330 & -0.986 & 0.299 & $* * *$ & 0.069 & 4.317 \\
\hline dt_6 & 0.133 & & 0.087 & 1.526 & -0.574 & $*$ & 0.337 & -1.705 & 0.022 & & 0.067 & 0.325 \\
\hline dt_7 & 0.143 & & 0.104 & 1.370 & -0.456 & & 0.338 & -1.347 & 0.274 & $* * *$ & 0.083 & 3.290 \\
\hline dt_8 & 0.270 & $* *$ & 0.121 & 2.230 & -0.180 & & 0.340 & -0.529 & 0.643 & $* * *$ & 0.082 & 7.881 \\
\hline dt_9 & 0.210 & & 0.134 & 1.567 & -0.246 & & 0.345 & -0.715 & 0.651 & $* * *$ & 0.106 & 6.144 \\
\hline $\mathrm{dt} \_10$ & 0.221 & $*$ & 0.121 & 1.828 & -0.238 & & 0.345 & -0.689 & 0.793 & $* * *$ & 0.106 & 7.509 \\
\hline dt_11 & 0.356 & $* * *$ & 0.135 & 2.634 & -0.123 & & 0.346 & -0.354 & 0.949 & $* * *$ & 0.110 & 8.619 \\
\hline $\mathrm{dt} \_12$ & 0.375 & $* * *$ & 0.136 & 2.746 & -0.248 & & 0.346 & -0.718 & 0.814 & $* * *$ & 0.114 & 7.145 \\
\hline dt_13 & 1.319 & $* * *$ & 0.149 & 8.870 & 1.171 & $* * *$ & 0.364 & 3.217 & 4.627 & $* * *$ & 0.230 & 20.085 \\
\hline Mean dep. & 2.00 & \multirow{3}{*}{\multicolumn{3}{|c|}{$\begin{array}{l}\text { Joint test on named } \\
\text { regressors: Chi-sq = } \\
69.941(p<0.0001)\end{array}$}} & 1.35 & \multirow{3}{*}{\multicolumn{3}{|c|}{$\begin{array}{l}\text { Joint test on named } \\
\text { regressors: } \text { Chi-sq }= \\
4.295(p<0.2313)\end{array}$}} & 1.22 & \multicolumn{3}{|c|}{ Joint test on named } \\
\hline SSR & 1828.46 & & & & 7301.54 & & & & 2591.49 & regre & essors: Chi & $-s q=$ \\
\hline Log-likel. & -2681.04 & & & & -4013.04 & & & & -3016.55 & 5.823 & $3(p<0.12$ & 05) \\
\hline Schwarz & 5483.08 & \multirow{8}{*}{\multicolumn{3}{|c|}{$\begin{array}{l}\text { Wald test: Chi-sq = } \\
285.478(p<0.0001)\end{array}$}} & 8147.07 & \multicolumn{3}{|c|}{$\begin{array}{l}\text { Wald test: Chi-sq = } \\
390.810(p<0.0001)\end{array}$} & 6154.09 & \multirow{8}{*}{\multicolumn{3}{|c|}{$\begin{array}{l}\text { Wald test: } \text { Chi-sq }= \\
767.824(p<0.0001)\end{array}$}} \\
\hline S.D. dep. & 1.02 & & & & 1.99 & & & & 1.64 & & & \\
\hline S.E. & 0.98 & & & & 1.96 & & & & 1.17 & & & \\
\hline Akaike & 5394.08 & & & & 8058.07 & & & & 6065.09 & & & \\
\hline Hannan-Quinn & 5426.82 & & & & 8090.82 & & & & 6097.84 & & & \\
\hline \begin{tabular}{|l|l} 
Between' & \\
\end{tabular} & 0.56 & & & & 0.44 & & & & 0.63 & & & \\
\hline Within' & 0.38 & & & & 3.39 & & & & 0.73 & & & \\
\hline theta & 0.77 & & & & 0.39 & & & & 0.71 & & & \\
\hline
\end{tabular}

The impact of biogas plants differs across vulnerability models which could thus potentially confuse farmers, managers and other stakeholders. In the case of Altman's model, the operation of biogas plants significantly worsens the score, by -0.636 on average, although 
not to the extent that farms become seriously vulnerable. The mean value of Altman's score is 2 which falls within the "grey zone". By contrast, Altman's score increased after farms received investment support which improves their cash flows. Overall, on average, Altman's score does not differ between participants and nonparticipants. This is a crucial finding because it suggests that public investment support for building agricultural biogas plants is not justified.

The G-index, tailored for agricultural companies, significantly decreases where biogas plants are in operation, albeit at the 0.1 significance level only. On average, the G-index does not differ between participants and nonparticipants. However, G-index scores significantly changed after farms received investment subsidies, albeit at the 0.1 significance level only. Overall, the joint test on named regressors did not reveal any joint significance between those regressors.

Let us now turn to exploring the credit scoring models in more detail to show roots of dissimilarities. Table 4 compares regression coefficients associated with all variables in Altman's model.

Table 4 | Effects of operating a biogas plant on partial indicators of Altman's scoring model

\begin{tabular}{|c|c|c|c|c|c|c|c|c|c|c|c|c|c|c|c|}
\hline \multirow[b]{2}{*}{ Variables } & \multicolumn{3}{|c|}{ AltX1 } & \multicolumn{3}{|c|}{ AltX2 } & \multicolumn{3}{|c|}{ AltX3 } & \multicolumn{3}{|c|}{ AltX4 } & \multicolumn{3}{|c|}{ AltX5 } \\
\hline & coeff. & sig. & SE & coeff. & sig. & SE & coeff. & sig. & SE & coeff. & sig. & SE & coeff. & sig. & SE \\
\hline const & 0.275 & $* * *$ & 0.013 & 0.163 & $* * *$ & 0.021 & 0.046 & $* * *$ & 0.007 & 1.959 & $* * *$ & 0.200 & 0.716 & $* * *$ & 0.017 \\
\hline OPER & -0.055 & $* * *$ & 0.009 & -0.073 & $* * *$ & 0.010 & 0.007 & & 0.006 & -1.072 & $* * *$ & 0.181 & -0.105 & $* * *$ & 0.015 \\
\hline PAYMENT & 0.040 & $* * *$ & 0.009 & 0.054 & $* * *$ & 0.011 & 0.000 & & 0.006 & 0.798 & $* * *$ & 0.164 & 0.092 & $* * *$ & 0.013 \\
\hline PARTICIP & -0.018 & & 0.015 & -0.034 & & 0.028 & 0.002 & & 0.005 & -0.309 & & 0.277 & -0.021 & & 0.023 \\
\hline$d t \_2$ & 0.015 & $* * *$ & 0.005 & 0.024 & *** & 0.009 & -0.009 & & 0.009 & 0.058 & & 0.055 & -0.015 & $*$ & 0.008 \\
\hline dt_3 & 0.011 & & 0.007 & 0.048 & $* * *$ & 0.008 & -0.010 & & 0.008 & 0.167 & *** & 0.056 & -0.012 & & 0.010 \\
\hline dt_4 & 0.026 & $* * *$ & 0.008 & 0.058 & *** & 0.009 & 0.025 & $* * *$ & 0.008 & 0.457 & *** & 0.126 & 0.006 & & 0.012 \\
\hline dt_5 & -0.002 & & 0.009 & 0.095 & $* * *$ & 0.010 & -0.003 & & 0.008 & 0.323 & $* *$ & 0.135 & -0.040 & $* * *$ & 0.013 \\
\hline dt_6 & -0.021 & $* *$ & 0.010 & 0.130 & *** & 0.011 & -0.038 & $* * *$ & 0.008 & 0.620 & *** & 0.183 & -0.106 & $* * *$ & 0.012 \\
\hline $\mathrm{dt} \_7$ & -0.045 & $* * *$ & 0.011 & 0.120 & $* * *$ & 0.013 & -0.017 & * & 0.009 & 0.538 & $* *$ & 0.210 & -0.100 & $* * *$ & 0.015 \\
\hline dt_8 & -0.042 & $* * *$ & 0.012 & 0.128 & $* * *$ & 0.014 & 0.016 & $*$ & 0.008 & 0.524 & $* *$ & 0.256 & -0.079 & $* * *$ & 0.015 \\
\hline dt_9 & -0.066 & $* * *$ & 0.015 & 0.148 & $* * *$ & 0.017 & 0.008 & & 0.009 & 0.495 & $*$ & 0.277 & -0.101 & $* * *$ & 0.020 \\
\hline $\mathrm{dt} \_10$ & -0.065 & $* * *$ & 0.015 & 0.172 & $* * *$ & 0.018 & 0.007 & & 0.009 & 0.492 & $* *$ & 0.247 & -0.107 & $* * *$ & 0.019 \\
\hline $\mathrm{dt} \_11$ & -0.047 & $* * *$ & 0.015 & 0.203 & $* * *$ & 0.019 & 0.015 & & 0.009 & 0.637 & $* *$ & 0.285 & -0.098 & $* * *$ & 0.020 \\
\hline $\mathrm{dt} \_12$ & -0.047 & $* * *$ & 0.015 & 0.241 & $* * *$ & 0.020 & -0.013 & & 0.009 & 0.830 & $* * *$ & 0.285 & -0.107 & $* * *$ & 0.020 \\
\hline dt_13 & -0.046 & $* * *$ & 0.015 & 0.250 & $* * *$ & 0.021 & 0.325 & $* * *$ & 0.020 & 0.971 & $* * *$ & 0.294 & -0.281 & $* * *$ & 0.021 \\
\hline Mean dep. & 0.222 & & & 0.246 & & & 0.074 & & & 1.924 & & & 0.596 & & \\
\hline SSR & 24.74 & & & 61.28 & & & 11.63 & & & 7646.781 & & & 47.466 & & \\
\hline Log-likel. & 1458.34 & & & 585.67 & & & 2184.62 & & & -4057.48 & & & 831.44 & & \\
\hline Schwarz & -2795.69 & & & -1050.35 & & & -4248.24 & & & 8235.96 & & & -1541.88 & & \\
\hline S.D. dep. & 0.123 & & & 0.188 & & & 0.119 & & & 2.016 & & & 0.185 & & \\
\hline S.E. & 0.114 & & & 0.179 & & & 0.078 & & & 2.001 & & & 0.158 & & \\
\hline Akaike & -2884.69 & & & -1139.35 & & & -4337.24 & & & 8146.96 & & & -1630.87 & & \\
\hline Hannan-Quinn & -2851.94 & & & -1106.61 & & & -4304.49 & & & 8179.70 & & & -1598.13 & & \\
\hline Between' & 0.01 & & & 0.03 & & & 0.00 & & & 2.44 & & & 0.01 & & \\
\hline Within' & 0.01 & & & 0.01 & & & 0.01 & & & 1.53 & & & 0.01 & & \\
\hline theta & 0.77 & & & 0.87 & & & 0.27 & & & 0.79 & & & 0.78 & & \\
\hline Joint test & 42.13 & $* * *$ & & 62.93 & $* * *$ & & 3.00 & & & 53.03 & $* * *$ & & 75.73 & $* * *$ & \\
\hline Wald test & 92.13 & $* * *$ & & 498.63 & $* * *$ & & 691.50 & $* * *$ & & 76.57 & $* * *$ & & 1290.29 & $* * *$ & \\
\hline
\end{tabular}

Notes: AltX1 = (current assets - current liabilities) / total assets; AltX2 = retained earnings / total assets; AltX3 = earnings before interest and taxes / total assets; AltX4 = book value of equity / total liabilities; AltX5 = revenues / total assets 
Altman's scoring model is adversely affected by the operation of biogas plants. This means that default risk increases after farmers launch a biogas plant. Table 4 shows that operating a biogas plant has an adverse impact on net working capital per assets (AltX1), long-term profitability (AltX2), capital structure (AltX4) and asset turnover (AltX5) but no impact on current profitability ROA (AltX3).

Further, net working capital increased but less than total assets. As was revealed in Table 1, investment in biogas plants causes growth in fixed assets which also adversely affects asset turnover. The lower book value per total liabilities results from the use of bank loans and other liabilities associated with investment expenditures and debt service coverage needed to co-finance biogas plants. Receipt of payment from the RDP, however, improves most indicators except profitability ROA (Dvouletý, 2017). The reason why no positive impact of profitability ROA is yielded lies in the different impacts of biogas plant on assets. Whereas total assets increase because of higher value of buildings and equipment, there are no discernible positive effects on land area and livestock (Table 1). A previous study revealed a positive impact of biogas plants on profit per hectare (Špička \& Krause, 2013). Another reason for this lack of effect on profitability can be seen in the fact that a significant share of the value added is transferred via increased rental prices to land owners (Appel et al., 2016) even though such prices are lower in the Czech Republic relative to Western Europe. From a financial management perspective, it is important to focus on the period from investment expenditure to receipt of subsidy which often takes up to two years.

IN05 and Altman's model have two common variables - profitability ROA (AltX3 = INX3) and asset turnover (AltX5 = INX4). Thus, Table 5 presents random effects regressions for three remaining variables - INX1 which denotes total assets to total liabilities (proxy for capital structure), INX2 interest coverage (earnings before interest and taxes / interest payable), INX5 current assets to short-term liabilities which provides information about liquidity of short-term assets (Gibson, 2013). 
Table 5 | Effects of operating a biogas plant on selected indicators of the IN05 credit scoring model - indicators not included in Altman's model

\begin{tabular}{|c|c|c|c|c|c|c|c|c|c|}
\hline \multirow[b]{2}{*}{ Variables } & \multicolumn{3}{|c|}{ INX1 } & \multicolumn{3}{|c|}{ INX2 } & \multicolumn{3}{|c|}{ INX5 } \\
\hline & coeff. & sig. & SE & coeff. & sig. & SE & coeff. & sig. & SE \\
\hline const & 2.961 & $* * *$ & 0.201 & 2.865 & & 2.338 & 7.778 & $* *$ & 3.553 \\
\hline OPER & -1.075 & $* * *$ & 0.182 & 0.495 & & 0.510 & -0.306 & & 0.364 \\
\hline PAYMENT & 0.802 & $* * *$ & 0.164 & -2.474 & & 2.838 & -0.336 & & 0.616 \\
\hline PARTICIP & -0.311 & & 0.277 & 4.500 & & 4.324 & -0.067 & & 0.909 \\
\hline dt_2 & 0.061 & & 0.056 & -9.474 & & 8.840 & -3.158 & & 3.832 \\
\hline dt_3 & 0.170 & $* * *$ & 0.057 & -1.108 & $* * *$ & 0.369 & -3.102 & & 3.984 \\
\hline dt_4 & 0.465 & *** & 0.127 & -5.586 & & 7.056 & -2.856 & & 3.999 \\
\hline dt_5 & 0.328 & $* *$ & 0.135 & -0.982 & $* * *$ & 0.351 & -3.399 & & 4.007 \\
\hline $\mathrm{dt} \_6$ & 0.625 & $* * *$ & 0.184 & -4.767 & $* * *$ & 0.808 & -3.180 & & 3.987 \\
\hline $\mathrm{dt} \_7$ & 0.541 & $* *$ & 0.210 & -2.557 & $* *$ & 1.102 & -3.597 & & 3.963 \\
\hline $\mathrm{dt} \_8$ & 0.528 & $* *$ & 0.256 & 1.397 & $*$ & 0.848 & -3.671 & & 3.942 \\
\hline dt_9 & 0.498 & * & 0.277 & 1.019 & & 1.249 & -3.649 & & 3.931 \\
\hline dt_10 & 0.499 & ** & 0.248 & 0.853 & & 1.416 & -3.374 & & 3.922 \\
\hline dt_11 & 0.641 & ** & 0.285 & 1.677 & & 1.510 & -3.039 & & 3.905 \\
\hline dt_12 & 0.834 & *** & 0.286 & 0.350 & & 1.522 & -2.903 & & 3.911 \\
\hline $\mathrm{dt} \_13$ & 0.976 & $* * *$ & 0.294 & 3.715 & $* *$ & 1.539 & -3.327 & & 3.900 \\
\hline Mean dep. & 2.929 & & & 3.654 & & & 4.462 & & \\
\hline SSR & 7673.63 & & & 2804971 & & & 364881 & & \\
\hline Log-likel. & -4060.85 & & & -9738 & & & -7775.89 & & \\
\hline Schwarz & 8242.70 & & & 19597 & & & 15672.77 & & \\
\hline S.D. dep. & 2.019 & & & 38.364 & & & 13.815 & & \\
\hline S.E. & 2.005 & & & 38.332 & & & 13.825 & & \\
\hline Akaike & 8153.70 & & & 19507.92 & & & 15583.77 & & \\
\hline Hannan-Quinn & 8186.45 & & & 19540.66 & & & 15616.51 & & \\
\hline Between' & 2.44 & & & 163.03 & & & 6.43 & & \\
\hline Within' & 1.54 & & & 1310.73 & & & 185.08 & & \\
\hline theta & 0.79 & & & 0.38 & & & 0.17 & & \\
\hline Joint test & 53.06 & *** & & 3.76 & & & 3.99 & & \\
\hline Wald test & 76.77 & *** & & 273.12 & $* * *$ & & 27.62 & $* * *$ & \\
\hline
\end{tabular}

Notes: INX1 $=$ total assets to total liabilities, INX2 $=$ interest coverage (earnings before interest and taxes / interests payable), INX5 = current assets to short-term liabilities.

Indicator "total assets to total liabilities" (INX1) is a suitable variable for estimation of investment impacts. Values of this indicator dropped following investments to biogas plants because of changes in capital structure but then increased after the farm received payment. The upper limit of interest coverage (INX2) biased the real impact of biogas plants on farms' financial stability. The interest coverage, with an upper limit at 9, does not depend at all on biogas plants. Finally, there are no discernible impacts of investment on the liquidity of current assets (INX5) because the strategic investments affect relatively long-term liabilities and solvency rather than the short-term liquidity of farms.

The reason why the operation of biogas plants does not influence the IN05 scoring model is apparent. Model IN05 has two variables affected by the biogas plant - assets turnover and capital structure. The profitability ROA has the highest weight in the IN05 model but is not influenced by the biogas plant as we discussed earlier.

Unlike Altman's and IN05 models, the G-index was developed for agricultural companies. It suggests a significant adverse effect of investment on biogas plants on vulnerability risk 
at the 0.1 significance level. In fact, the original purpose of the G-index was not to predict bankruptcy but to elucidate possible financial difficulties facing agricultural companies. The G-index considers that companies are risky if they have experienced a loss in three consecutive years (Gurcik, 2002). The G-index shows that investment in biogas plant slightly worsens the financial conditions of the farm. Moreover, the receipt of payment from the RDP does not affect the G-index. The first two variables of the G-index were calculated in Altman's model - long-term profitability (GX1 = AltX2) and ROA (GX2 = AltX3). Table 6 provides information about the remaining variables in the G-index not included in Altman's model or IN05 - profit margin GX3 (earnings before interest and taxes / total revenues), CFROA GX4 (cash flow / total assets, where cash flow = net profit + non-cash costs) and GX5 (stock / total revenues).

The reason why the G-index yields different results than Altman's model arises from how the model is constructed. Four of the five indicators in the model represent profitability. The G-index does not consider changes in the capital structure or liquidity of assets. Thus, the model is not suitable for complex assessment of strategic corporate investments. Table 6 shows that profit margin is positively affected by investment in biogas plants at the 0.05 significance level. The CFROA is adversely affected by biogas plants (cash flow drop), but receipt of the subsidy positively affects the CFROA (cash flow growth). The indicator "stock / total revenues" is independent of investment to biogas plants. The effects on the CFROA and ROA are different because of depreciation and amortisation, which significantly increase after launching biogas plants and are non-cash costs (Špička \& Krause, 2013). Thus, strategic investments in biogas plants positively influence cash flow instead of profit. 
Table 6 | Effects of operating a biogas plant on selected indicators of the G-index - indicators not included in Altman's or IN05 models

\begin{tabular}{|c|c|c|c|c|c|c|c|c|c|}
\hline \multirow[b]{2}{*}{ Variables } & \multicolumn{3}{|c|}{ GX3 } & \multicolumn{3}{|c|}{ GX4 } & \multicolumn{3}{|c|}{ GX5 } \\
\hline & coeff. & sig. & SE & coeff. & sig. & SE & coeff. & sig. & SE \\
\hline const & 0.067 & $* * *$ & 0.010 & 0.134 & $* * *$ & 0.006 & 0.363 & $* * *$ & 0.013 \\
\hline OPER & 0.032 & $* *$ & 0.015 & -0.012 & $* * *$ & 0.004 & -0.006 & & 0.009 \\
\hline PAYMENT & -0.022 & & 0.016 & 0.018 & $* * *$ & 0.003 & 0.002 & & 0.009 \\
\hline PARTICIP & 0.006 & & 0.009 & 0.003 & & 0.006 & 0.002 & & 0.015 \\
\hline $\mathrm{dt} \_2$ & -0.014 & & 0.012 & -0.010 & & 0.007 & -0.013 & & 0.008 \\
\hline dt_3 & -0.015 & & 0.011 & -0.005 & & 0.007 & -0.026 & $* * *$ & 0.007 \\
\hline dt_4 & 0.033 & $* * *$ & 0.011 & 0.020 & $* * *$ & 0.007 & -0.043 & $* * *$ & 0.010 \\
\hline dt_5 & -0.003 & & 0.011 & -0.010 & & 0.007 & -0.010 & & 0.010 \\
\hline dt_6 & -0.051 & $* * *$ & 0.011 & -0.038 & $* * *$ & 0.007 & 0.023 & $* *$ & 0.009 \\
\hline$d t \_7$ & -0.017 & & 0.012 & -0.024 & $* * *$ & 0.008 & -0.019 & $* *$ & 0.009 \\
\hline dt_8 & 0.035 & $* * *$ & 0.012 & 0.000 & & 0.007 & -0.029 & $* * *$ & 0.010 \\
\hline dt_9 & 0.026 & $*$ & 0.016 & -0.007 & & 0.008 & -0.038 & $* *$ & 0.016 \\
\hline $\mathrm{dt} \_10$ & 0.025 & & 0.017 & -0.003 & & 0.007 & -0.062 & $* * *$ & 0.013 \\
\hline $\mathrm{dt} \_11$ & 0.037 & $* *$ & 0.017 & 0.007 & & 0.007 & -0.044 & $* * *$ & 0.013 \\
\hline $\mathrm{dt} \_12$ & -0.012 & & 0.018 & -0.013 & & 0.008 & -0.052 & $* * *$ & 0.013 \\
\hline $\mathrm{dt} \_13$ & 1.025 & $* * *$ & 0.057 & -0.013 & & 0.008 & 0.126 & $* * *$ & 0.017 \\
\hline Mean dep. & 0.164 & & & 0.127 & & & 0.347 & & \\
\hline SSR & 76.19 & & & 5 & & & 22 & & \\
\hline Log-likel. & 376.21 & & & 3004 & & & 1557.61 & & \\
\hline Schwarz & -631.43 & & & -5887 & & & -2994.23 & & \\
\hline S.D. dep. & 0.342 & & & 0.053 & & & 0.117 & & \\
\hline S.E. & 0.200 & & & 0.051 & & & 0.108 & & \\
\hline Akaike & -720.43 & & & -5975.66 & & & -3083.23 & & \\
\hline Hannan-Quinn & -687.69 & & & -5942.91 & & & -3050.48 & & \\
\hline Between' & 0.00 & & & 0.00 & & & 0.01 & & \\
\hline Within' & 0.04 & & & 0.00 & & & 0.01 & & \\
\hline theta & 0.20 & & & 0.66 & & & 0.73 & & \\
\hline Joint test & 7.36 & $*$ & & 56.89 & $* * *$ & & 0.50 & & \\
\hline Wald test & 739.57 & & & 326.11 & $* * *$ & & 569.41 & $* * *$ & \\
\hline
\end{tabular}

Notes: GX3 = profit margin (earnings before interest and taxes / total revenues), GX4 = CFROA (cash flow / total assets, where cash flow $=$ net profit + non-cash costs), GX5 = stock $/$ total revenues. 
Table 7 | Effects of operating a biogas plant on economic sustainability

\begin{tabular}{|c|c|c|c|}
\hline \multirow[b]{2}{*}{ Variables } & \multicolumn{3}{|c|}{ Economic sustainability } \\
\hline & \begin{tabular}{|l|} 
coeff. \\
\end{tabular} & sig. & SE \\
\hline const & 645.198 & $* * *$ & 117.149 \\
\hline LIC & -3779.205 & $* * *$ & 305.611 \\
\hline BGP & 878.159 & $* * *$ & 235.490 \\
\hline PAYMENT & 725.865 & $* * *$ & 157.653 \\
\hline PARTICIP & -222.795 & & 162.538 \\
\hline$d t \_2$ & 287.818 & $* *$ & 117.541 \\
\hline dt_3 & 34.843 & & 129.529 \\
\hline dt_4 & -362.238 & $* *$ & 143.718 \\
\hline dt_5 & 536.632 & $* * *$ & 178.288 \\
\hline dt_6 & -431.307 & $*$ & 230.616 \\
\hline dt_7 & -638.358 & $* * *$ & 219.006 \\
\hline dt_8 & -967.463 & $* * *$ & 278.140 \\
\hline dt_9 & -879.307 & $* * *$ & 316.192 \\
\hline $\mathrm{dt} \_10$ & -485.217 & & 299.084 \\
\hline $\mathrm{dt} \_11$ & -339.719 & & 255.112 \\
\hline dt_12 & -953.330 & $* *$ & 378.289 \\
\hline Mean dep. & 525.276 & & \\
\hline SSR & 7471557990 & & \\
\hline Log-likel. & -16064.03 & & \\
\hline Schwarz & 32247.78 & & \\
\hline S.D. dep. & 2361.578 & & \\
\hline S.E. & 2059.804 & & \\
\hline Akaike & 32160.07 & & \\
\hline Hannan-Quinn & 32192.47 & & \\
\hline Between' & 293733 & & \\
\hline Within' & 3933360 & & \\
\hline theta & 0.27 & & \\
\hline Joint test & 261.50 & $* * *$ & \\
\hline Wald test & 63.09 & $* * *$ & \\
\hline
\end{tabular}

Table 7 presents the model for economic sustainability. The results therein clearly show that investment in biogas plants decrease economic sustainability in the short term, by -3779 thousand EUR on average. This can place economic viability at risk because the mean economic sustainability is only 525.3 thousand EUR. In the long-term, however, operating biogas plants improves economic sustainability by 878.2 thousand EUR due to the revenues from guaranteed output price and green bonuses. Moreover, receipt of the subsidy improves cash flow and economic sustainability. Thus, biogas production provides an attractive profitable income opportunity, especially for large farms, which has led to a boost in biogas production (Appel et al., 2016). During the whole sample period, participants did not exhibit significantly different economic sustainability compared to nonparticipants which confirms 
our earlier results concerning the deadweight loss effects of public investment support from the RDP on large farms (Ratinger et al., 2013).

\section{Conclusion}

This article offers a long-term economic assessment of agricultural biogas plants to provide a frame-of-reference for farmers and other salient stakeholders who seek to understand the possible and plausible costs and benefits of this economically and environmental controversial means of renewable energy production.

The chief goal of this article was to evaluate impacts of biogas plants on the economic sustainability and vulnerability of farms. The results have implications for strategic management as well as policymakers. Overall, investments in biogas plants can render agricultural companies economically less viable in the short term. When the company asks for investment subsidies, management personnel must adequately focus on the period between investment expenditure (usually co-financed by a bank loan) and receipt of the payment from the public payment authority. This period is characterised by high indebtedness and inadequate revenues because the biogas plant is under construction. The results show that investment expenditures in biogas plants quite often exceeded the value of assets which makes them strategic. Farms which invested in biogas plants suffer from debt pressures without significant increased return on assets (ROA).

In the long term, the effects of biogas plant operations on economic sustainability and vulnerability are positive as the company receives public investment support after completion and revenues from energy sales, via feed-in tariffs or green bonuses. Public support for renewable energy production is a substantial part of the current subsidies mix in mixed type farming contexts, accounting for a $17 \%$ share on average in 2016 . This could lead to distortions in agricultural and land markets.

The results show that it is important to select appropriate models for predicting business failure. Scoring models, such as Altman's model, which consider not only profitability but also capital structure are suitable for impact evaluation of strategic investment decisions. The results show that operating biogas plants has an adverse impact on net working capital per unit of assets, long-term profitability, capital structure and asset turnover. Alternatively, the vulnerability models which place the most emphasis on current profitability (IN05, Gindex) do not adequately capture the empirical realities of farms' finances because there is no impact of biogas plants on return on assets.

Renewable energy production through biogas plants has been heavily subsidised. The biogas farms ask for current subsidies and investment subsidies. Current subsidies are essential for ensuring farms' viability and sustainability in the current economic conditions because most types of farming cannot cover operating costs by production without these subsidies. The results revealed that the specific investment support of renewable energy production 
increases the cash flow of the farm and economic sustainability. The current subsidies are granted through feed-in tariffs and green bonuses linked to the amount of electricity produced. Such support is under the responsibility of the Energy Regulatory Office. Current subsidies for renewable energy production make biogas stations thriving businesses in the long term, especially for medium and large companies. The need for economies of scale and high investment expenditures creates entry barriers for small farms that were not able to invest in biogas.

The associated goal of this article was to compare economic sustainability and vulnerability between supported and unsupported farms over 2004 to 2016. The random effects regression model did not reveal any significant differences between these farms types in terms of the metrics operationalised in this paper. This indicates a high deadweight loss effect which means that programme participants would undertake a similar investment without programme support (Dvouletý et al., 2018).

Developing the use of agricultural biomass as a renewable energy source is a key strategic objective of macro (i.e. the European Commission) and meso (i.e. individual Member States) level agricultural policy in the European Union. The use of biomass as a renewable energy source has been developing rapidly, particularly regarding agricultural biogas stations. However, this development is often at the expense of sustainable soil management. It can be assumed that the new conditions of support will dampen the further development of these plants, at least in terms of how they are currently instituted, in response to prevailing critiques concerning sub-optimally excessive use of public funds. Recent studies highlight the availability of sufficient sustainable alternatives to the use of maize to ensure the further development of the European biogas sector.

It would be fruitful for future research to focus on agricultural biogas plants in the context of smaller companies compared to the sample used herein. Unfortunately, such companies are only a marginal segment of agricultural biogas plants in the Czech Republic because of prevailing farm structures in that country where large farms dominate agricultural production. As such, although the results generated in this study may be generalisable to the national level, whether and the extent to which they generalise to other country contexts where smaller farms are more commonplace, remains to be determined.

\section{Acknowledgement}

Financial support from the Czech Ministry of Education, Youth and Sports is gratefully acknowledged (Institutional support for long-term conceptual development of the research organization University of Economics, Prague, IGS grant No. F3/46/2017).

\section{References}

Abbas, T., Ali, G., Adil, S. A., Bashir, M. K., \& Kamran, M. A. (2017). Economic analysis of biogas adoption technology by rural farmers: The case of Faisalabad district in 
Pakistan. Renewable Energy, 107, 431-439.

https://doi.org/10.1016/j.renene.2017.01.060

Agarwal, V., \& Taffler, R. (2008). Comparing the performance of market-based and accounting-based bankruptcy prediction models. Journal of Banking \& Finance, 32(8), 1541-1551. https://doi.org/10.1016/j.jbankfin.2007.07.014

Alaka, H. A., Oyedele, L. O., Owolabi, H. A., Kumar, V., Ajayi, S. O., Akinade, O. O., \& Bilal, M. (2018). Systematic review of bankruptcy prediction models: Towards a framework for tool selection. Expert Systems with Applications, 94, 164-184. https://doi.org/10.1016/j.eswa.2017.10.040

Allison, P. D. (2009). Fixed Effects Regression Models. Quantitative applications in the social sciences: 07-160. London: SAGE.

Altman, E. I., \& Hotchkiss, E. (2005). Corporate Financial Distress and Bankruptcy. Hoboken, NJ: John Wiley \& Sons.

Anderson, W. L., \& Ross, R. L. (2005). The methodology of profit maximization: An Austrian alternative. The Quarterly Journal of Austrian Economics, 8(4), 31-44. https://doi.org/10.1007/s12113-005-1002-9

Appel, F., Ostermeyer-Wiethaup, A., \& Balmann, A. (2016). Effects of the German Renewable Energy Act on structural change in agriculture - The case of biogas. Utilities Policy, 41, 172-182. https://doi.org/10.1016/j.jup.2016.02.013

Arellano, M. (2003). Panel Data Econometrics. Oxford: Oxford University Press.

Bartolini, F., Gava, O., \& Brunori, G. (2017). Biogas and EU's 2020 targets: Evidence from a regional case study in Italy. Energy Policy, 109, 510-519. https://doi.org/10.1016/j.enpol.2017.07.039

Bonazzi, G., \& Iotti, M. (2015). Evaluation of Biogas Plants by the Application of an Internal Rate of Return and Debt Service Coverage Approach. American Journal of Environmental Sciences, 11(1), 35-45. https://doi.org/10.3844/ajessp.2015.35.45

Boritz, J. E., Kennedy, D. B., \& Albuquerque, A. D. M. E. (1995). Predicting Corporate Failure Using a Neural Network Approach. Intelligent Systems in Accounting, Finance and Management, 4(2), 95-111. https://doi.org/10.1002/j.10991174.1995.tb00083.x

Börjesson, P., \& Tufvesson, L. M. (2011). Agricultural crop-based biofuels - resource efficiency and environmental performance including direct land use changes. Journal of Cleaner Production, 19(2-3), 108-120. https://doi.org/10.1016/j.jclepro.2010.01.001

Bossel, H. (1999). Indicators for sustainable development: Theory, method, applications: A report to the Balaton Group. Winnipeg: International Institute for Sustainable Development.

Brealey, R. A., Myers, S. C., \& Allen, F. (2008). Principles of Corporate Finance. Boston, MA: McGraw-Hill/Irwin.

Britz, W., \& Delzeit, R. (2013). The impact of German biogas production on European and global agricultural markets, land use and the environment. Energy Policy, 62, 12681275. https://doi.org/10.1016/j.enpol.2013.06.123 
Brudermann, T., Mitterhuber, C., \& Posch, A. (2015). Agricultural biogas plants - A systematic analysis of strengths, weaknesses, opportunities and threats. Energy Policy, 76, 107-111. https://doi.org/10.1016/j.enpol.2014.11.022

Camska, D. (2016). Accuracy of models predicting corporate bankruptcy in a selected industry branch. Ekonomický časopis, 64(4), 353-366.

Czech Biogas Association (2018). Data on licenced agricultural plants.

Delzeit, R., \& Kellner, U. (2013). The impact of plant size and location on profitability of biogas plants in Germany under consideration of processing digestates. Biomass and Bioenergy, 52, 43-53. https://doi.org/10.1016/j.biombioe.2013.02.029

Demartini, E., Gaviglio, A., Gelati, M., \& Cavicchioli, D. (2016). The Effect of Biogas Production on Farmland Rental Prices: Empirical Evidences from Northern Italy. Energies, 9(11), 965-987. https://doi.org/10.3390/en9110965

Dougherty, C. (2011). Introduction to Econometrics. Oxford: Oxford University Press. Dvouletý, O. (2017). Effects of Soft Loans and Credit Guarantees on Performance of Supported Firms: Evidence from the Czech Public Programme START.

Sustainability, 9(12), 2293. https://doi.org/10.3390/su9122293

Dvouletý, O., Forman, D., Machalický, J., Kinda, L., Havlíček, R., \& Hanuš, A. (2018).

Would Entrepreneurs Have Started Their Businesses even Without Receiving Public Support? Reflection on the Czech Programme START. Trendy v podnikání, 8(1). https://doi.org/10.24132/jbt.2018.8.1.25_32

Eder, A., \& Mahlberg, B. (2018). Size, Subsidies and Technical Efficiency in Renewable Energy Production: The Case of Austrian Biogas Plants. The Energy Journal, 39(1), 185-210. https://doi.org/10.5547/01956574.39.1.aede

European Commission - Directorate-General for Agriculture and Rural Development (2016). Methodological Handbook for Implementing an Ex-Ante Assessment of Agriculture Financial Instruments under the EAFRD. Luxembourg: European Investment Bank.

Forti, R. (2017). Agriculture, forestry and fishery statistics: 2017 edition. Luxembourg: Publications Office.

Garbs, M., \& Geldermann, J. (2018). Analysis of selected economic and environmental impacts of long distance manure transports to biogas plants. Biomass and Bioenergy, 109, 71-84. https://doi.org/10.1016/j.biombioe.2017.12.009 Gibson, C. H. (2013). Financial Statement Analysis. Mason, OH: South-Western. Ginting, N., Zuhri, F., Hasnudi, Mirwandhono, E., Sembiring, I., \& Daulay, A. H. (2018). Financial analysis of biogas utilization: Input cattle, pig feces and coffee waste in Karo, Indonesia. IOP Conference Series: Earth and Environmental Science, 122, 15. https://doi.org/10.1088/1755-1315/122/1/012128

Greene, W. H. (2012). Econometric analysis. Boston, MA: Pearson Education. Guenther-Lübbers, W., Bergmann, H., \& Theuvsen, L. (2016). Potential analysis of the biogas production - as measured by effects of added value and employment. Journal of Cleaner Production, 129, 556-564. https://doi.org/10.1016/j.jclepro.2016.03.157 
Gurcik, L. (2002). G-index - the financial situation prognosis method of agricultural enterprises. Agricultural Economics (Zemédělská Ekonomika), 48(8), 373-378.

Hanibal, J. (Ed.). (2017). Results of the FADN CZ survey 2016. Prague: Institute of Agricultural Economics and Information.

Huang, Z., Chen, H., Hsu, C.-J., Chen, W.-H., \& Wu, S. (2004). Credit rating analysis with support vector machines and neural networks: A market comparative study. Decision Support Systems, 37(4), 543-558. https://doi.org/10.1016/S01679236(03)00086-1

Chen, M.-Y. (2011). A hybrid model for business failure prediction -- Utilization of particle swarm optimization and support vector machines. Neural Network World, 21(2), 129-152. https://doi.org/10.14311/NNW.2011.21.009

Cho, S., Hong, H., \& Ha, B.-C. (2010). A hybrid approach based on the combination of variable selection using decision trees and case-based reasoning using the Mahalanobis distance: For bankruptcy prediction. Expert Systems with Applications, 37(4), 3482-3488. https://doi.org/10.1016/j.eswa.2009.10.040

Iotti, M., \& Bonazzi, G. (2016). Assessment of biogas plant firms by application of annual accounts and financial data analysis approach. Energies, 9(9), 713-731. https://doi.org/10.3390/en9090713

Kizeková, M., Hopkins, A., Kanianska, R., Makovníková, J., Pollák, Š., \& Pálka, B. (2018). Changes in the area of permanent grassland and its implications for the provision of bioenergy: Slovakia as a case study. Grass and Forage Science, 73(1), 218-232. https://doi.org/10.1111/gfs.12333

Klepac, V., \& Hampel, D. (2017). Predicting financial distress of agriculture companies in EU. Agricultural Economics (Zemědělská Ekonomika), 63(8), 347-355. https://doi.org/10.17221/374/2015-AGRICECON

Kolodner, J. (1993). Case-Based Reasoning. San Mateo, CA: Morgan Kauffman Publishers.

Kopta, D. (2009). Possibilities of financial health indicators used for prediction of future development of agricultural enterprises. Agricultural Economics (Zemédělská Ekonomika), 55(3), 111-125.

Krause, J., \& Machek, O. (2018). A comparative analysis of organic and conventional farmers in the Czech Republic. Agricultural Economics (Zemédělská Ekonomika), 64(1), 1-8.

Latruffe, L., Diazabakana, A., Bockstaller, C., Desjeux, Y., Finn, J., Kelly, E., . . Uthes, S. (2016). Measurement of sustainability in agriculture: A review of indicators. Studies in Agricultural Economics, 118(3), 123-130. https://doi.org/10.7896/j.1624

Manasova, Z. (2008). Insolvency of the Czech companies its timely prediction. Doctoral dissertation. Prague: University of Economics.

Mckee, T. E. (2000). Developing a bankruptcy prediction model via rough sets theory. International Journal of Intelligent Systems in Accounting, Finance \& Management, 9(3), 159-173. https://doi.org/10.1002/1099-

1174(200009)9:3<159::AID-ISAF184>3.0.CO;2-C 
Megginson, W. L. (1997). Corporate Finance Theory. Reading, MA: Addison-Wesley. Meyer, A.K.P., Ehimen, E. A., \& Holm-Nielsen, J. B. (2018). Future European biogas:

Animal manure, straw and grass potentials for a sustainable European biogas production. Biomass and Bioenergy, 111, 154-164.

https://doi.org/10.1016/j.biombioe.2017.05.013

Min, S.-H., Lee, J., \& Han, I. (2006). Hybrid genetic algorithms and support vector machines for bankruptcy prediction. Expert Systems with Applications, 31(3), 652660. https://doi.org/10.1016/j.eswa.2005.09.070

Ministry of Agriculture. (2008). The Rural Development Programme of the Czech

Republic 2007 - 2013. Prague. Retrieved November 30, 2018 from

http://eagri.cz/public/web/file/10574/RDP_November_2008.pdf.

Ministry of Agriculture (2018). Data about investment subsidies of biogas plants. Prague:

Ministry of Agriculture, Czech Republic.

Modigliani, F., \& Miller, M. H. (1958). The cost of capital, corporation finance and the theory of investment. The American Economic Review, 48(3), 261-297.

Modigliani, F., \& Miller, M. H. (1963). Corporate income taxes and the cost of capital: A correction. The American Economic Review, 53(3), 433-443.

Morris, R. (1997). Early warning indicators of corporate failure: A critical review of previous research and further empirical evidence / Richard Morris. Aldershot: Ashgate.

Neumaierova, I., \& Neumaier, I. (2005). Index IN05. In P. Cervinek (Ed.), European Financial Systems (pp. 143-148). Brno: Masaryk University.

O'Donoghue, C., Devisme, S., Ryan, M., Conneely, R., Gillespie, P., \& Vrolijk, H. (2016). Farm economic sustainability in the European Union: A pilot study. Studies in Agricultural Economics, 118(3), 163-171. https://doi.org/10.7896/j.1631

Ohlson, J. A. (1980). Financial ratios and the probabilistic prediction of bankruptcy. Journal of Accounting Research, 18(1), 109-131. https://doi.org/10.2307/2490395

Ostermeyer, A., \& Schonau, F. (2012). Effects of biogas production on inter- and in-farm competition (No. 708-2016-48449). Prague. Retrieved November 11, 2018 from http://ageconsearch.umn.edu/record/135772/files/Ostermeyer.pdf.

Ratinger, T., Medonos, T., \& Hruska, M. (2013). An assessment of the differentiated effects of the investment support to agricultural modernisation: the case of the Czech Republic. Agris On-line Papers in Economics and Informatics, 5(4), 153164.

Sgroi, F., Donia, E., \& Alesi, D. R. (2018). Renewable energies, business models and local growth. Land Use Policy, 72, 110-115. https://doi.org/10.1016/j.landusepol.2017.12.028

Shin, K.-S., \& Lee, Y.-J. (2002). A genetic algorithm application in bankruptcy prediction modeling. Expert Systems with Applications, 23(3), 321-328. https://doi.org/10.1016/S0957-4174(02)00051-9

Slaboch, J., \& Hálova, P. (2016). The Influence of investment costs on biogas station development and their impact on greenhouse gas emissions from Czech agriculture. 
Agris On-line Papers in Economics and Informatics, 8(4), 143-151.

https://doi.org/10.7160/aol.2016.080413

Špička, J. (2015). Insolvency in agriculture - impact of current subsidies on financial position. In M. Čulík (Ed.): Financial Management of Firms and Financial Institutions, Financial Management of Firms and Financial Institutions: 10th International Scientific Conference (pp. 1279-1284). Ostrava: VSB Ostrava.

Špička, J., \& Krause, J. (2013). Selected socioeconomic impacts of public support for agricultural biogas plants: The case of the Czech Republic. Bulgarian Journal of Agricultural Science, 19(5), 929-938.

Špička, J., Naglova, Z., \& Gurtler, M. (2017). Effects of the investment support in the Czech meat processing industry. Agricultural Economics (Zemédělská ekonomika), 63(8), 356-369. https://doi.org/10.17221/367/2015-AGRICECON

Swamy, P. A. V. B., \& Arora, S. S. (1972). The exact finite sample properties of the estimators of coefficients in the error components regression models. Econometrica, 40(2), 261-275. https://doi.org/10.2307/1909405

Vochozka, M., Maroušková, A., \& Šuleř, P. (2018). Economic, environmental and moral acceptance of renewable energy: A Case Study-The Agricultural Biogas Plant at Pěčín. Science and Engineering Ethics, 24(1), 299-305. https://doi.org/10.1007/s11948-017-9881-7

Walla, C., \& Schneeberger, W. (2008). The optimal size for biogas plants. Biomass and Bioenergy, 32(6), 551-557. https://doi.org/10.1016/j.biombioe.2007.11.009

Watson, I. D. (1997). Applying case-based reasoning: Techniques for enterprise systems. San Francisco, CA: Morgan Kaufmann.

Wilcox, J. W. (1973). A prediction of business failure using accounting data. Journal of Accounting Research, 11, 163-179. https://doi.org/10.2307/2490035

Wilson, R. L., \& Sharda, R. (1994). Bankruptcy prediction using neural networks. Decision Support Systems, 11(5), 545-557. https://doi.org/10.1016/01679236(94)90024-8

Yasar, A., Nazir, S., Tabinda, A. B., Nazar, M., Rasheed, R., \& Afzaal, M. (2017). Socioeconomic, health and agriculture benefits of rural household biogas plants in energy scarce developing countries: A case study from Pakistan. Renewable Energy, 108(August), 19-25. https://doi.org/10.1016/j.renene.2017.02.044

Yeh, C.-C., Chi, D.-J., \& Lin, Y.-R. (2014). Going-concern prediction using hybrid random forests and rough set approach. Information Sciences, 254, 98-110. https://doi.org/10.1016/j.ins.2013.07.011

Zmijewski, M. E. (1984). Methodological issues related to the estimation of financial distress prediction models. Journal of Accounting Research, 22, 59-82. https://doi.org/10.2307/2490859

\section{Author}




\section{Jindřich Špička}

Faculty of Business Administration

University of Economics, Prague

nám. W. Churchilla 4

13067 Praha 3, Czech Republic

jindrich.spicka@vse.cz 